\title{
Leguminous Biopharmaceutechs
}

\author{
Akbar Nikkhah* \\ *Department of Animal Sciences, University of Zanjan, Iran \\ Submission: November 19, 2016; Published: November 22, 2016 \\ *Corresponding author: Akbar Nikkhah, Department of Animal Sciences, University of Zanjan, Iran, Email: anikkha@yahoo.com
}

\section{Philosophy and Discussion}

Plant-origin therapeutics includes pharmaceuticals, multi-constituent botanical drugs, dietary supplements, functional foods and plant-derived recombinant proteins and vaccines. These products will complement conventional pharmaceuticals for cure and diagnosis of diseases, while improving agriculture. Advanced biotechnologies to generate preferential biopharmaceuticals (BP) are receiving increased research and commercial interests. However, the cost, safety, and accessibility of such BP are among the major challenges. A main advantage of leguminous crops, namely alfalfa (Medicago Sativa), is their immense biomass yield. Leguminous plants contain phytoestrogens that encompass several compounds, such as flavonoids, isoflavonoids, coumestans, and lignans. Despite a possibility of causing animal infertility, phytoestrogens may be beneficial to human health and prevent cancer, act as antioxidants, scavenge free radicals, lower circulating cholesterol, and be anti-estrogenic [1,2].

Legumes such as peas, soybeans, and alfalfa can be used to produce plant-derived inexpensive monoclonal antibodies (plantibodies) for human and animal therapeutics. Recent findings suggest that high phytoestrogens doses may adversely affect brain differentiation and reproductive maturity in rodents. Due to the presence of a multitude of bioactive substances in legumes, further studies particularly involving nutrigenomics and metabolomics are required to specify such effects on human health indicators of particular BP. These achievements will form new perspectives for healthier plant-human-animal ecologies $[1,3]$. The emerging biotechnologies of mainly plant-origin and legume-derived pharmaceutical proteins production encounter real challenging. The biotechnologists and their supporting sciences and industries should convince lawmaking and ethical organizations, and the major investing companies in the economical and viable nature of the technologies compared to those established previously. Careful monitoring and utilization of the initial products are a must for compelling validation of the methods and regulatory frameworks.
As such, the new proteins in forms of vaccines and antibodies have the real opportunity to improve health and life quality of large human and animal populations. Due to the presence of a multitude of bioactive substances in legumes, further studies particularly involving nutrigenomics and metabolomics are required to attribute and specify BP effects on human health indicators. Quantitative and qualitative dietary inclusion guidelines for food and feed packages and preparations with legume origins may become feasible for different animal and human age groups. These accomplishments will contribute to forming healthy and viable plant-human-animal biotechnologies in the new era $[2,4]$. Genetic engineering helps to produce biopharmaceuticals most favorable to human and animal health. Alfalfa is a multi-cut leguminous plant with high annual biomass yield. Alfalfa leaves and seeds are main targets of 'biopharming' or 'biopharmaceuticals production of farming'. With increasing demands for plant-made biopharmaceuticals, their production could be safer and cheaper than animal-derived counterparts. Alfalfa is an inexpensive platform for monoclonal antibodies, which are used as potential human therapeutics and diagnostics [2].

Plant expression systems to produce human and animal vaccines possess many advantages. These include easilyestablished cultivation, inexpensive production, no or little demand for cold-chain supply, rapid scale-up, simple seed distribution, easy genetic manipulation, oral supply capacity, and minor health concerns of human pathogen and toxin contaminations. Plant-derived antibodies have passed the earlystage clinical trials. It may well be feasible in the near future to sweep away diseases by eating tasty vegetables and fruits. However, the existing main concerns include biosafety, dosage uniformity, regulatory guidelines, and possible survival of herbicides and pesticides [1-4]. The human vaccine technology using plants may become feasible based on technical merits and approvals from public and social sectors. Future research on enhancing the expression of special genes is needed. It must be 
ensured that how and if transgenic plant vaccines meet quality standards (purity, potency, safety, and efficacy) of the World Health Organization.

\section{Acknowledgments}

Thanks to the Ministry of Science Research and Technology, University of Zanjan, and National Elite Foundation for supporting the author's global programs of optimizing science edification in the third millennium.

\section{References}

1. Nikkhah A (2014) Legumes as Medicine: Nature Prescribes. Med Aromat Plants 3:e153.

2. Nikkhah A (2013) Legumes Biofarming and Biopharmaceutical Sciences: A Review. Res J Medicin Plant 6: 466-488.

3. Nikkhah A (2012) Legume Biotechnopharmaceutics. LAP LAMBERT Publishing, GmbH and Co KG, Germany.

4. Nikkhah A (2012) Alfalfa the Bountiful Leading Crop of All Times' Ecologies: Emerging Biopharm and Medicinal Implications. In Alfalfa and Clovers: Properties, Medicinal Uses and Health Benefits. (Eds) Fiala J, Pospíšil D, Nova Science Publishers, NY, USA.

Your next submission with JuniperPublishers will reach you the below assets

- Quality Editorial service

- Swift Peer Review

- Reprints availability

- E-prints Service

- Manuscript Podcast for convenient understanding

- Global attainment for your research

- Manuscript accessibility in different formats (Pdf, E-pub, Full Text, Audio)

- Unceasing customer service

Track the below URL for one-step submission http://juniperpublishers.com/online-submission.php 